\title{
Correction to "Implementation of Technology-based Patient Engagement Strategies within Practice-Based Research Networks"
}

In the above-mentioned article, ${ }^{1}$ the electronic version differs from the print version due to the placement of the figures. While the figure headings for Figure 1 and 2 are correct, the figures themselves were flipped during the processing of the article. The electronic version on the Journal of the American Board of Family Medicine website has been corrected. We apologize for the error, and we regret any confusion or inconvenience it may have caused.

doi: $10.3122 / j a b f m .2017 .04 .170208$

To see this article online, please go to: bttp://jabfm.org/content/30/4/561.full.

\section{Reference}

1. Careyva B, Shaak K, Mills G, et al. Implementation of technology-based patient engagement strategies within practice-based research networks. J Am Board Fam Med 2016;29:581-91. 